NR 19 (28)

BIBLIOTEKA

2015 PL ISSN 1506-3615

$\begin{array}{lllllllllll}W & S & P & O & M & N & \text { I } & \text { E } & \text { N } & \text { I } & \text { E }\end{array}$

\title{
Bożena Cofta-Małecka
}

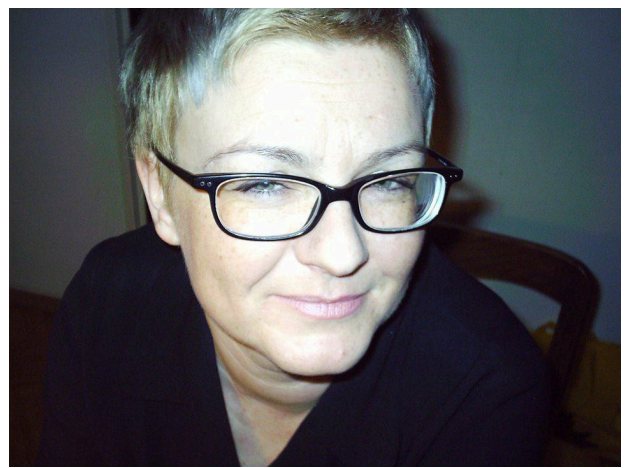

Urodziła się w Poznaniu w maju 1964 roku. Ojciec, prof. Henryk Cofta, pochodzący ze starej poznańskiej rodziny, był wówczas docentem w Katedrze Fizyki Teoretycznej Uniwersytetu im. Adama Mickiewicza. Mama, Urszula Cofta z domu Kęsy, również pracowała naukowo w Instytucie Fizyki Uniwersytetu im. Adama Mickiewicza, wówczas na stanowisku asystenta. Świat szczęśliwego dzieciństwa Bożeny Cofty-Małeckiej umiejscowiony był na poznańskim Starym Grunwaldzie. Czteropokojowe mieszkanie na trzecim piętrze $\mathrm{w}$ bloku przy ulicy Marcelińskiej wypełnione było książkami i dobrą muzyką klasyczną. Ojciec Henryk grywał w nim na pianinie, a Bożena muzycznie realizowała się w szkolnym chórze. Książki i dobra muzyka towarzyszyć jej będą przez całe życie.

W 1978 roku rozpoczęła naukę w II Liceum Ogólnokształcącym im. Heleny Modrzejewskiej (dziś II LO im. Generałowej Zamoyskiej i Heleny Modrzejewskiej) przy ulicy Jana Matejki w Poznaniu. Regina Domowicz-Śmigiel - wychowawczyni Bożeny, dziś emerytowana nauczycielka języka polskiego z II Liceum Ogólnokształcącego - tak ją wspomina:

Należała do uczniów nieprzeciętnych, nie ze względu na oceny i wybitne osiągnięcia w nauce. Posiadała już w młodym wieku, jako 16-letnia dziewczyna, osobliwe jak na swój wiek cechy. Należały do nich wrażliwość, kultura osobista i pewna dojrzałość. Lata jej nauki w II Liceum Ogólnokształcącym przypadały na czasy niezwykle burzliwe - strajków, powstania Solidarności i wprowadzenia stanu wojennego. Klasa na czele ze swoją przewodniczącą Bożenką Coftą opowiedziała się po stronie Solidarności i bez względu na grożące konsekwencje, straszenie przez niektórych nauczycieli niezdaniem matury stała lojalnie 
po stronie krzywdzonych przez własną partię robotników. Wrażliwość Bożeny miała nie tylko charakter polityczny. Często, narażając się na szykany, broniła kolegów przed Jej zdaniem niesprawiedliwością. Posiadała również inny rodzaj wrażliwości - estetyczna, pisała wiersze i była klasowym bardem, stylizując się na Janis Joplin. Stanowiła duszę życia kulturalnego klasy i pozaszkolnego towarzystwa. Brała na swoje barki trudniejsze zadania, pertraktując z nauczycielami przedmiotów terminy prac klasowych i sprawdzianów, przeważnie z powodzeniem, było to zasługą jej osobistej kultury. Zdarzało się, iż na lekcjach wychowawczych czy też języka polskiego stawiała mi trudne pytania. Bożena mówiła wprost. Oczekiwała jasnej, konkretnej odpowiedzi, nie zadowalając się eufemizmami. Świat postrzegała w barwach czarno-białych. Była indywidualistką i już wówczas zdawała sobie $z$ tego sprawę. Pielęgnowała swą odrębność, nie ulegając modom i trendom. Często spotykała się z tego powodu z brakiem akceptacji, lecz wiedziała, że jest to cena, którą należy zapłacić. Opierała się wszelkiej uniformizacji, pragnąc pozostać jednostką niepowtarzalną. Jako młoda buntowniczka nie godziła się na kompromisy i taka pozostała do końca swojego krótkiego życia. Po kilkudziesięciu latach nawiązałyśmy znów bliski kontakt. Ze zdziwieniem stwierdziłam, iż mimo gorzkich i traumatycznych doświadczeń pozostała osobą o wielkiej wrażliwości, niosącą pomoc wszystkim potrzebującym, krzywdzonym przez los i poszkodowanym przez życie ${ }^{1}$.

Bożena Cofta-Małecka ukończyła w maju 2002 roku studia magisterskie na kierunku kulturoznawstwo na Uniwersytecie im. Adama Mickiewicza w Poznaniu. Temat pracy magisterskiej napisanej pod kierunkiem prof. dra hab. Jana Grada brzmiał Współczesne młodzieżowe obrzędy przejścia (obchody osiemnastych urodzin i zdania matury). W 2009 roku Bożena ukończyła studia podyplomowe w Instytucie Filologii Polskiej i Klasycznej UAM na kierunku bibliotekoznawstwo i informacja naukowa.

Zawodowo z Uniwersytetem im. Adama Mickiewicza związała się w 1998 roku. Początkowo pracowała jako samodzielny referent w Katedrze Filologii Słowiańskiej Wydziału Filologii Polskiej i Klasycznej UAM, w 2005 roku podjęła obowiązki na stanowisku samodzielnego referenta w Dziekanacie Wydziału Filologii Polskiej i Klasycznej UAM. W czerwcu 2007 roku stała się pracownikiem bibliotecznym. Początkowo zatrudniona została na stanowisku młodszego bibliotekarza w Bibliotece Instytutu Etnologii i Antropologii Kulturowej Wydziału Historycznego UAM, a w grudniu 2009 roku rozpoczęła pracę w Bibliotece Uniwersyteckiej, w której zdobywała kolejne bibliotekarskie stopnie: od młodszego bibliotekarza, poprzez bibliotekarza i - od czerwca 2014 roku - starszego

\footnotetext{
${ }^{1}$ Wspomnienie Reginy Domowicz-Śmigielowej, rękopis, własność prywatna, s. 1-2.
} 
bibliotekarza. W kwietniu 2013 roku odbyła staż zawodowy w Bibliotece Głównej Uniwersytetu Medycznego w Poznaniu.

Po przejściu do pracy w Bibliotece Uniwersyteckiej aktywnie włączyła się w działalność kulturalną. Każdego roku brała udział w konkursach organizowanych przez Koło Stowarzyszenia Bibliotekarzy Polskich. W 2013 roku zajęła drugie miejsce w konkursie „Lepiejada”, w 2014 roku została wyróżniona w konkursie na najlepszy BUskalik. Przygotowywała wystawę o poznańskiej rodzinie Coftów, której niestety z powodu przedwczesnego odejścia nie zdążyła ukończyć. Miłośniczka dobrej literatury nie mogła obejść się bez oryginalnych zakładek do książek. Zgromadziła ich 153. Prosiła przyjaciół, by z każdej wyprawy przywieźli dla niej zakładkę, a współpracownicy z Wypożyczalni wyłapywali zakładki, które w książkach zostawiali czytelnicy.

Przyjaźnie nawiązane w okresie pracy na Wydziale Filologii Polskiej i Klasycznej UAM pielęgnowała przez następne lata. Tak wspomina ją dr hab. Izabela Lis-Wielgosz z Instytutu Filologii Słowiańskiej UAM:

Bożenka była mi bardzo bliska, lubiłam Jej poczucie humoru, to była jedna z nielicznych osób, które potrafiły mnie po prostu rozbawić - czasem drobiazgiem, szalonym słówkiem, zresztą obie lubowałyśmy się w dość specyficznej grze słów, operowaniu nowosłowiem, wymyślaniu historyjek, dosłownie wyplataniu barwnych opowiastek, które czasem tylko dla nas były zrozumiałe i tylko nas rozweselały w danej chwili. Bożenka lubiła bawić się słowem pisała krótkie tekściki, fraszki, moskaliki, ale też teksty piosenek, uwielbiała muzykę i wplecioną w nią sensowną treść. Rzec można, że była nawet tak pozytywnie starodawna czy klasyczna w postrzeganiu świata, życia, ludzi, ale umiała też przymykać oczy na mniejszą czy większą głupotę i niewrażliwość, była tolerancyjna w sprawach małych i dużych. Nie będzie przesada, jak powiem, że uwielbiała ludzi i wiele im przez to wybaczała czy puszczała płazem, kochała ludzi i wierzyła w ich dobrą substancję, potrafiła ich rozumieć i wyzwalać pozytywną energię. Oczywiście muszę dodać, że kochała też zwierzęta, i to bardzo. Bożenka była raczej wesoła, ale też za tym Jej promiennym uśmiechem kryło się wiele niełatwych sytuacji, spora suma trudnych doświadczeń życiowych, mimo to starała się dostrzegać cierpienie i zmaganie innych. Była osobą bardzo wrażliwą i inteligentną emocjonalnie, wiele naszych rozmów dotyczyło spraw ważnych i poważnych czy nawet ciężkich gatunkowo, ceniłam sobie i do dziś cenię te rozmowy, ale tę sferę pozostawię już tylko dla siebie. Bożenka była dobrym i przyzwoitym człowiekiem, zawsze chętna do pomocy, czasem wręcz szaleńczo chętna, dosłownie biegała, dzwoniła, dowiadywała się, jak coś załatwić, jak pomóc, jak doradzić, jak wesprzeć. Myślę, że wiele osób ma u Niej dług wdzięczności, wiele nie umiało odwzajemnić 
Jej zaangażowania, zrozumieć altruistycznego poświęcenia i docenić szczerej sympatii, jednak wiele osób potrafiło się odwdzięczyć własną atencją, wielu się o Nią troszczyło, wielu tych, którym była rzeczywiście bliska. Jej śmierć była autentycznym wstrząsem, odejściem, z którym łatwo czy w ogóle pogodzić się nie można. Często myślę o Bożence, często jest mi smutno, że już Jej nie ma „tutaj", ale muszę wyznać, że podejrzewam, co może robić „tam”..., i dlatego się uśmiecham².

W 1986 roku poślubiła Wojciecha Małeckiego, którego poznała na terenie Akademickiego Związku Sportowego w Kiekrzu. Żeglarstwo było ich największą wspólną pasją. Z małżeństwa urodziła się w 1990 roku córka Urszula.

Wchodząc do starego gmachu Biblioteki Uniwersyteckiej i na pierwszym piętrze kierując się w prawo, znajdziemy się w pomieszczeniu po dawnej Czytelni Niemieckiej, które dziś pełni funkcję Klubu BU. Stowarzyszenie Bibliotekarzy Polskich działające przy Bibliotece ogłosiło w kwietniu 2014 roku konkurs na jego nazwę. Bożenka do konkursu wysłała cztery propozycje: BUKącik, BUCafe, Bibliorelaks i BUKawka. Spośród dwudziestu czterech nadesłanych propozycji na nazwę Klubu Biblioteki Uniwersyteckiej jury wybrało propozycję Bożenki - BUKawkę.

Nikt nie spodziewał się wówczas, że będzie to ostatnia twórcza rola Bożenki dla Biblioteki. Odeszła od nas 16 stycznia 2015 roku.

Damian Rożek-Pawłowski

\footnotetext{
${ }^{2}$ Wspomnienie Izabeli Lis-Wielgosz, rękopis, własność prywatna, s. 2.
} 